\title{
Cytotoxicity and antibacterial activities of crude extract of Streptomyces sp. W08, an endophyte of Amomum krervanh Pierre
}

\author{
Thongchai Taechowisan ${ }^{1 *}$, Tipparat Samsawat ${ }^{1}$, Winyou Puckdee ${ }^{1}$, Waya S. Phutdhawong ${ }^{2}$ \\ ${ }^{1}$ Department of Microbiology, Faculty of Science, Silpakorn University, Bangkok, Thailand. \\ ${ }^{2}$ Department of Chemistry, Faculty of Science, Silpakorn University, Bangkok, Thailand.
}

\begin{tabular}{l}
\hline ARTICLE INFO \\
\hline Received on: $18 / 01 / 2020$ \\
Accepted on: $02 / 05 / 2021$ \\
Available online: $05 / 08 / 2021$
\end{tabular}

Key words:

Anthraquinone, antibacterial activity, anticancer activity, cytotoxicity, Streptomyces.

\begin{abstract}
Strain W08 was isolated from the pseudostem tissue of Amomum krervanh Pierre (Zingiberaceae) and identified as Streptomyces sp. by analyzing its morphology, chemotaxonomy, and 16SrDNA sequence. It was shown to exert bactericidal effects against Bacillus cereus, Bacillus subtilis, Staphylococcus aureus, and methicillin-resistant $S$. aureus. Crude extract of its culture inhibited the tested bacteria, with minimum inhibitory concentrations of 32-128 $\mu \mathrm{g} / \mathrm{ml}$. The cytotoxicity of the crude extract was also assessed against cell lines using [3-(4,5-Dimethylthiazol-2-yl)2,5-Diphenyltetrazolium Bromide] colorimetric assay. The crude extract showed weak cytotoxic activity on L929 and Vero cells with IC50 values of 453.22 and $>512.00 \mu \mathrm{g} / \mathrm{ml}$, respectively. The most powerful cytotoxicity of the crude extract was observed in human cervical carcinoma cells and human breast carcinoma cells with IC50 values of 78.45 and $106.50 \mu \mathrm{g} / \mathrm{ml}$, respectively, while the IC 50 value of human hepatocellular carcinoma cells was $425.86 \mu \mathrm{g} / \mathrm{ml}$. The bioactive compounds in the extract were isolated by column chromatography and thin-layer chromatography, which were revealed by IR and NMR analyses to be 1-hydroxy-2-methyl-6-methoxyanthraquinone (1) and 6-methoxy-2methylquinizarin (2). The findings showed that the crude extract of Streptomyces sp. W08 containing the bioactive compounds exhibited antibacterial activity and selective cytotoxicity toward some cancer cells. The studies on these compounds could thus lead to useful approaches for managing some bacterial infections and cancers in the future.
\end{abstract}

\section{INTRODUCTION}

Amomum krervanh Pierre (Zingiberaceae) is a tropical plant that is widely distributed in Southeast Asia. It is used globally for spices and is commonly applied as folk medicine to treat stomach disorders (Yin et al., 2013a). The chemical composition of this plant has been reported (Wu et al., 2006; Yin et al., 2013a, 2013b; Zeng et al., 2012) and it has also been indicated that plants of the genus Amomum exhibit antioxidant (Teresita et al., 2000), antimicrobial (Diao et al., 2014; Kwon et al., 2003; Malti et al., 2007; Moon et al., 2004), anti-inflammatory (Choi et al., 2018; Lee et al., 2008; Mathew et al., 2003), and antimalarial activities (Kamchonwongpaisan et al., 1995).

\footnotetext{
"Corresponding Author

Thongchai Taechowisan, Department of Microbiology, Faculty of Science, Silpakorn University, Bangkok, Thailand.

E-mail: tewson84@hotmail.com
}

Recently, in studies on the endophytic actinomycetes, we isolated strain W08 from the pseudostem tissue of Amomиm krervanh Pierre. It has antibacterial activity against mostly Gram-positive bacteria. Herein, we report the cytotoxicity of its crude extract against two normal cell lines [murine epithelial cells (L929) and African green monkey kidney cells (Vero)] and three cancer cell lines [human breast carcinoma cells (MCF-7), human cervical carcinoma cells (HeLa), and human hepatocellular carcinoma cells (HepG2)] using a (3-(4,5-Dimethylthiazol-2-yl)2,5-Diphenyltetrazolium Bromide) (MTT) colorimetric assay. We also identified this strain, purified the major compounds, and also elucidated their structures.

\section{MATERIALS AND METHODS}

\section{Isolation, cultivation, and antibacterial screening of endophytic actinomycetes}

Various tissues of Amomum krervanh Pierre were used to isolate the endophytic actinomycetes as described in a previous study 
(Taechowisan et al., 2017). Ten actinomycete isolates were obtained and tested for their ability to produce antibacterial substances against Bacillus cereus ATCC 7064, Bacillus subtilis ATCC 6633, Escherichia coli ATCC 25922, methicillin-resistant Staphylococcus aureus Sp6, Pseudomonas aeruginosa ATCC 28753, and S. aureus ATCC 25923 using an overlay assay on ISP-2 agar plates, as previously described (Wu et al., 2015) with some modifications. Antibacterial screening of actinomycetes was carried out as described in a previous study (Taechowisan et al., 2017). Among the 10 isolates of actinomycetes, the results showed that the best production of antibacterial substances was achieved by isolate W08. This isolate was identified according to the methods of Taechowisan et al. (2003) and Taechowisan et al. (2017). The isolate W08 was grown on ISP-2 agar at $30^{\circ} \mathrm{C}$ for 14 days, and the culture was extracted with ethyl acetate as described in a previous study (Taechowisan et al., 2017).

\section{Minimum inhibitory concentration (MIC) and minimum bactericidal concentration (MBC)}

The MICs of the crude extract were carried out by the National Committee for Clinical Laboratory Standards microbroth dilution methods (National Committee for Clinical Laboratory Standards, 2000). The crude extract was initially dissolved in dimethyl sulfoxide (DMSO). The MIC and MBC were carried out as described in a previous study (Taechowisan et al., 2017).

\section{MTT assay for cytotoxicity activity $\left(\mathrm{IC}_{50}\right)$}

The normal cell lines [murine epithelial cells (L929) and African green monkey kidney cells (Vero)] and three cancer cell lines [HeLa, human hepatocellular carcinoma cells (HepG2), and MCF-7] were used to assess the $\mathrm{IC}_{50}$ of the crude extract using MTT assay as described in a previous study (Taechowisan et al., 2017).

\section{Purification and structural elucidation of major components}

Ethyl acetate extract ( $10.75 \mathrm{~g}$ ) was fractionated by silica gel 60 column chromatography and eluted with a mixture of petroleum ether-ethyl acetate with increasing polarity. Fractions eluted with $3.5 \%$ and then $8 \%$ ethyl acetate in petroleum ether were purified by thin-layer chromatography (TLC) (solvent: petroleum ether-ethyl acetate, 8.5:1.5 and 4:1) to give compounds $\mathbf{1}$ and $\mathbf{2}$, respectively. The purified compounds were then subjected to NMR spectroscopy.

\section{RESULTS AND DISCUSSION}

A total of 100 samples each of leaf, pseudostem, rhizome, and root tissues of Amomum krervanh Pierre were examined. The root tissue was the site where actinomycetes were most commonly isolated, where a total of $20 \%$ of actinomycetes were found (Table 1), which matches our previous report (Taechowisan et al., 2003). The roots thus present a good habitat for these endophytic actinomycetes. This may be related to the abundance of actinomycetes within the rhizosphere microbial flora (Sardi et al., 1992), enabling easier infection of host plants. The results showed that, against the tested microorganisms, isolate W08 showed promising activities (Table 2). A large number of endophytic actinomycete isolates have no potential antibacterial

Table 1. Isolated actinomycetes from different parts of Amomum krervanh Pierre.

\begin{tabular}{lcccc}
\hline \multirow{2}{*}{ Plant } & \multicolumn{3}{c}{ Actinomycete isolates from each plant parts } \\
\cline { 2 - 5 } & Leaf & Pseudostem & Rhizome & Root \\
\hline & & & W09 & W15 \\
\multirow{2}{*}{ Amomum krevvanh Pierre } & W02 & W08 & W32 & W29 \\
& & & W33 & W31 \\
& & & $3(12 \%)$ & W34 \\
\hline Number of isolates & $1(4 \%)$ & $1(4 \%)$ & & $5(20 \%)$ \\
\hline
\end{tabular}

Table 2. Screening for antibacterial activity of actinomycetes using an overlay assay.

\begin{tabular}{ccccccc}
\hline \multirow{2}{*}{$\begin{array}{c}\text { Actinomycete } \\
\text { isolates }\end{array}$} & \multicolumn{7}{c}{ Inhibition index on tested microorganisms } \\
\cline { 2 - 7 } & B.c. $^{\text {a }}$ & B.s. & S.a. & MRSA & E.c. & P.a. \\
\hline W02 & - & - & - & - & - & - \\
W08 & $5.89 \pm 0.20$ & $4.21 \pm 0.23$ & $6.30 \pm 0.39$ & $5.42 \pm 0.33$ & - & - \\
W09 & - & - & - & - & - & - \\
W15 & - & - & - & - & - & - \\
W24 & - & - & - & - & - & - \\
W29 & - & - & - & - & - & - \\
W31 & - & $1.43 \pm 0.52$ & $1.43 \pm 0.57$ & - & - & - \\
W32 & - & $3.02 \pm 1.00$ & $3.63 \pm 0.05$ & - & - & - \\
W33 & - & $4.13 \pm 0.30$ & $3.88 \pm 0.52$ & - & - & - \\
W34 & - & $2.16 \pm 0.51$ & - & - & - & - \\
\hline
\end{tabular}

${ }^{\mathrm{a} B . c . ;}$ B. cereus ATCC 7064, B.s.; B. subtilis ATCC 1248, S.a.; S. aureus. ATCC 25923, MRSA; methicillin-resistant S. aureus Sp6 (the clinical isolate), E.c.; E. coli ATCC 25922 and P.a.; P. aeruginosa ATCC 28753 
activity against the tested bacteria. As stated in several reports, endophytic actinomycete activity influences the metabolic products of actinomycetes acting on plant growth and physiology (Hasegawa et al., 2006; Igarashi et al., 2002; Manulis et al., 1994; Meguro et al., 2006; Mishra et al., 1987). Thus, most of them did not produce antimicrobial metabolic products.

Based on the results of morphological observation, isolate W08 formed extensive substrate mycelia and abundant aerial mycelia on agar medium. It produced aerial mycelia that differentiated into long spore chains. These spore chains were straight to flexuous (rectiflexibiles) with oval and smooth surface spores (Figure. 1). Its substrate mycelia were grayish-green to dark olive-brown and the aerial mycelia were greenish-white to light greenish-grey. Owing to features including the presence of LL-type diaminopimelic acid in the whole-cell extracts, isolate W08 was identified as Streptomyces. The 16S rDNA sequence was determined for isolate W08 (1,473 bp). The BLAST search results and the phylogenetic tree are presented in Table 3 and Figure 2, respectively. These results showed that isolate W08 has high levels of sequence similarity to Streptomyces coelicolor NBRC 12854 (accession number: AB184196) and Streptomyces felleus NBRC 12766 (accession number: AB184129). The 16S rDNA analysis showed that isolate W08 is phylogenetically also closely related to these strains. The $16 \mathrm{~S}$ rDNA sequence data reported in this paper are available in GenBank under accession number AB845558.

The antibacterial activity of the crude extract from Streptomyces sp. W08 culture is shown in Table 4. The crude extract inhibited the tested bacteria, with MICs and MBCs of $32-128 \mu \mathrm{g} / \mathrm{ml}$ and 256 to $>512 \mu \mathrm{g} / \mathrm{ml}$, respectively. However, no activity against Gram-negative bacteria was exhibited by this extract, which was due to the different composition of bacterial cell walls. The mechanisms of action of the crude extract may

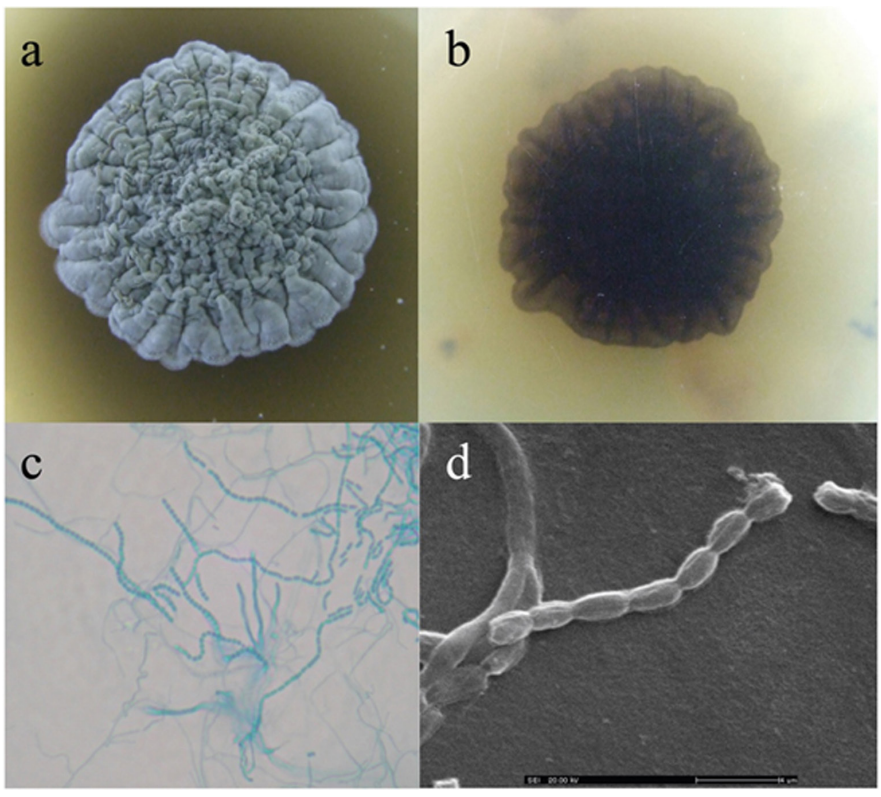

Figure 1. The morphological characteristics of Streptomyces sp. W08. The colony appearance [surface (a) and reverse (b)] of Streptomyces sp. W08 after 21 days of growth on ISP-2 agar at $30^{\circ} \mathrm{C}$ incubation. (c) a light micrograph and (d) a scanning electron micrograph; bar $=2 \mu \mathrm{m}$. involve antimicrobial effects, having different activity against Gram-negative and Gram-positive bacteria.

The crude extract showed weak cytotoxic activity against L929 and Vero cells, with IC $_{50}$ values of 453.22 and $>512.00 \mu \mathrm{g} /$ $\mathrm{ml}$, respectively (Table 5). The most powerful cytotoxicity of the crude extract was observed in HeLa and MCF-7 cells, with $\mathrm{IC}_{50}$ values of 78.45 and $106.50 \mu \mathrm{g} / \mathrm{ml}$, respectively, while the $\mathrm{IC}_{50}$ value against HepG2 cells was $425.86 \mu \mathrm{g} / \mathrm{ml}$. These data are interesting as they suggest that this crude extract is more toxic to some cancer cells than to normal cells, implying its potential as an anticancer agent. Although this preliminary anticancer study demonstrated that the crude extract exhibited an anticancer effect, more detailed investigation is required to isolate the bioactive compounds from the crude extract.

Among our observations of the cytotoxicity toward cancer cells, it was particularly interesting that the crude extract exhibited greater toxicity against $\mathrm{HeLa}$ and $\mathrm{MCF}-7$ cells than against L929 and Vero cells. In this context, the therapeutic index (TI) is an important parameter to select samples for developing drugs. This value is the ratio of the concentration of the crude extract at which $50 \%$ of the normal cell death to that of the crude extract at which $50 \%$ cancer cell death occurred. Further investigation is considered to be warranted if a TI value of $\geq 4$ is identified. The present study found TI values for this crude extract of $\geq 4$ for $\mathrm{HeLa}$ and MCF-7 cells. This extract is thus promising for further investigation as an anticancer agent.

Silica gel column chromatography and TLC with petroleum ether-ethyl acetate as the mobile phase resulted in the isolation of two major compounds, 1-hydroxy-2-methyl-6methoxyanthraquinone (1) and 6-methoxy-2-methylquinizarin (2), TOFMS m/z: 291.2533 (calcd for $\mathrm{C}_{16} \mathrm{H}_{12} \mathrm{O}_{4} \mathrm{Na}: 291.2532$ ) and 307.2527(calcd forC $\mathrm{C}_{16} \mathrm{H}_{12} \mathrm{O}_{5} \mathrm{Na}: 307.2525$ ), respectively(Figure.3).

Table 3. 16S rDNA similarity values between Streptomyces sp. W08 and representatives of the genus Streptomyces.

\begin{tabular}{|c|c|c|}
\hline Streptomyces species & $\begin{array}{l}\text { Similarity to } \\
\text { strain W08 }\end{array}$ & $\begin{array}{c}\text { No. of nucleotide } \\
\text { differences/total no. of } \\
\text { nucleotides compared }\end{array}$ \\
\hline S. coelicolor NBRC 12854 & 100.00 & $0 / 1452$ \\
\hline S. felleus NBRC 12766 & 100.00 & $0 / 1452$ \\
\hline $\begin{array}{l}\text { Streptomyces albidoflavus NBRC } \\
13010\end{array}$ & 99.93 & $1 / 1452$ \\
\hline Streptomyces canescens NBRC 12751 & 99.93 & $1 / 1452$ \\
\hline $\begin{array}{l}\text { Streptomyces coriofaciens NBRC } \\
13403\end{array}$ & 99.93 & $1 / 1452$ \\
\hline $\begin{array}{l}\text { Streptomyces champavatii NRRL } \\
\text { B-5682 }\end{array}$ & 99.86 & $2 / 1472$ \\
\hline Streptomyces fungicidicus $\mathrm{YH} 04$ & 99.66 & $5 / 1473$ \\
\hline Streptomyces koyangensis VK-A60 & 99.52 & $7 / 1473$ \\
\hline $\begin{array}{l}\text { Streptomyces flavofungini NBRC } \\
13371\end{array}$ & 98.34 & $24 / 1453$ \\
\hline Streptomyces exfoliatus NBRC 13191 & 96.06 & $57 / 1450$ \\
\hline $\begin{array}{l}\text { Streptomyces albus subsp. albus DSM } \\
40313 \mathrm{~T}\end{array}$ & 96.01 & $58 / 1455$ \\
\hline Streptomyces griseus KACC 20084 & 95.45 & $66 / 1451$ \\
\hline $\begin{array}{l}\text { Streptomyces globisporus subsp. } \\
\text { caucasicus NRRL B-2593 }\end{array}$ & 94.58 & $77 / 1423$ \\
\hline
\end{tabular}




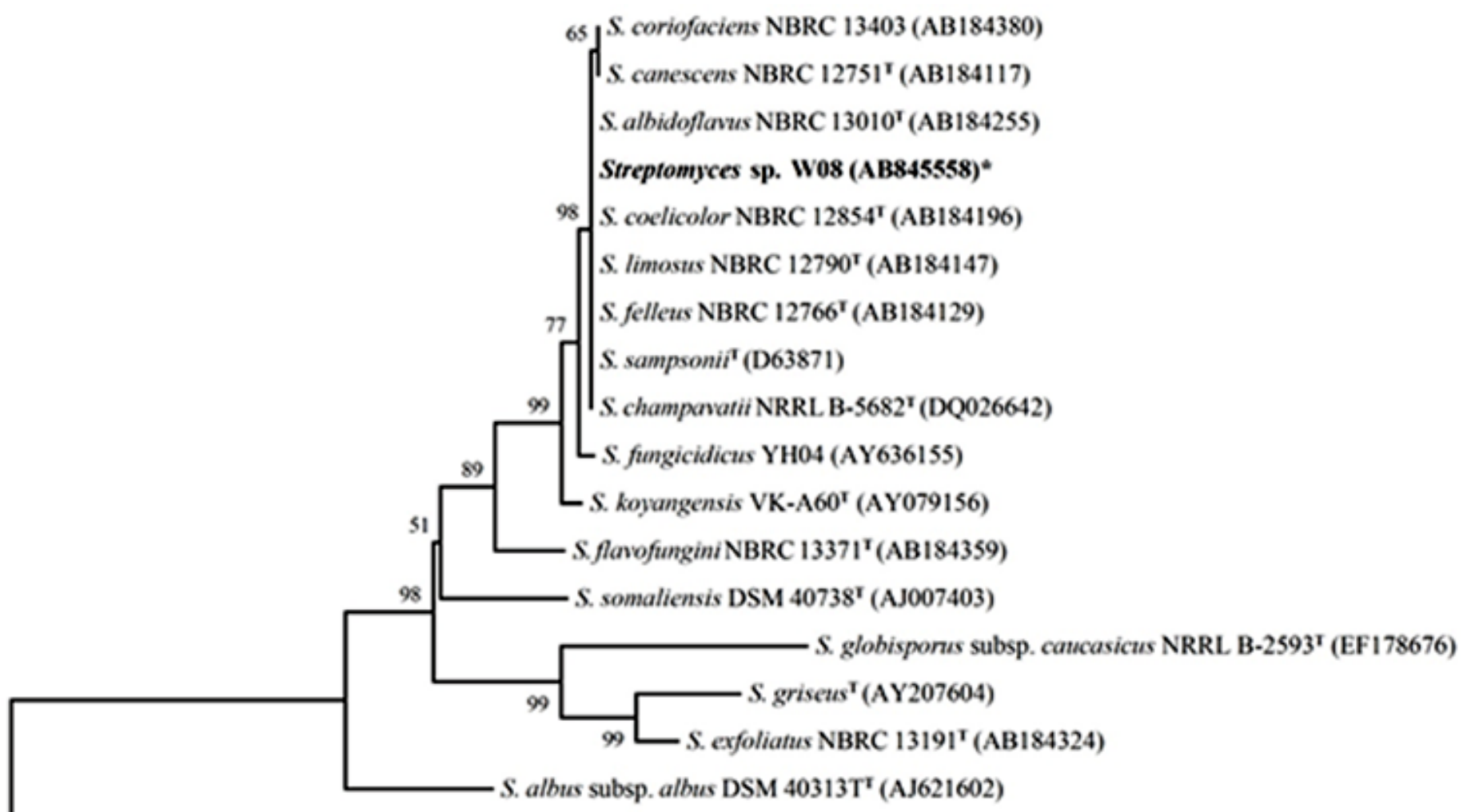

Mycobacterium tuberculosis H37Rv ${ }^{\mathrm{T}}$ (NR_102810)

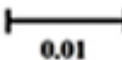

Figure 2. Neighbor-joining phylogenetic tree of isolate W08, including the closely related type strain base on 16SrDNA gene sequences which were retrieved from GenBank. Accession numbers appear in parentheses. Bootstrap (1,000 replicates) values are given in percentage. Bar, 0.01 substitutions per site.

Table 4. MIC and MBC of the crude extract from Streptomyces sp. W08 culture.

\begin{tabular}{lcc}
\hline Tested microorganisms & MIC $(\boldsymbol{\mu g} / \mathbf{m l})$ & MBC $(\boldsymbol{\mu g} / \mathbf{m l})$ \\
\hline B. cereus ATCC 7064 & 64 & 512 \\
B. subtilis ATCC 6633 & 128 & $>512$ \\
S. aureus ATCC 25932 & 32 & 256 \\
Methicillin-resistant S. aureus Sp6 & 64 & 256 \\
E. coli ATCC 25922 & $>512$ & $\mathrm{ND}$ \\
P. aeruginosa ATCC 28753 & $>512$ & $\mathrm{ND}$ \\
\hline
\end{tabular}

Table 5. $\mathrm{IC}_{50}$ and $\mathrm{TI}$ of the crude extract on various cell lines.

\begin{tabular}{cccccccc}
\hline \multicolumn{4}{c}{ IC50a $(\boldsymbol{\mu g} / \mathbf{m l})$} & \multicolumn{3}{c}{ TI $^{\mathbf{b}}$} \\
\hline L929 & Vero & MCF-7 & HeLa & HepG2 & MCF-7 & HeLa & HepG2 \\
\hline 453.22 & $>512.00$ & 106.50 & 78.45 & 425.86 & 4.25 & 5.77 & 1.06 \\
\hline
\end{tabular}

aIC50 values represent the concentration causing $50 \%$ growth inhibition.

${ }^{b} \mathrm{TI}$ is defined as the ratio of $50 \%$ toxic dose on normal cells to $50 \%$ effective dose on cancer cells (L929 cells were selected to determine the TI, while the IC50 value of Vero cells was $>512.00 \mu \mathrm{g} / \mathrm{ml})$

Their ${ }^{1} \mathrm{H}-\mathrm{NMR}$ and ${ }^{13} \mathrm{C}-\mathrm{NMR}$ spectral data were identical with those of 1-hydroxy-2-methyl-6-methoxyanthraquinone and 6-methoxy-2-methylquinizarin previously reported (El-Lakany et al., 2004). According to data from the literature, anthraquinone<smiles>[R]c1cc(C)c(O)c2c1C(=O)c1cc(OC)ccc1C2=O</smiles>

$$
\begin{aligned}
& 1 \mathrm{R}=\mathrm{H} \\
& 2 \mathrm{R}=\mathrm{OH}
\end{aligned}
$$

Figure 3. Chemical structures of 1-hydroxy-2-methyl-6-methoxyanthraquinone (1) and 6-methoxy-2-methylquinizarin (2).

compounds have been reported on antimicrobial activity (ElLakany et al., 2004; Mbaveng et al., 2008).

\section{CONCLUSION}

In summary, crude extract from the culture of Streptomyces sp. W08 showed antibacterial activity against Grampositive bacteria. It also exhibited potent cytotoxic effects on HeLa and MCF-7 cells, while exhibiting low cytotoxicity against normal cells (L929 and Vero cells). These results indicate that this 
crude extract may be a potential therapeutic candidate for treating some bacterial infections and cancers.

\section{ACKNOWLEDGMENT}

This work was supported by the Faculty of Science, Silpakorn University, Nakhon Pathom, Thailand.

\section{AUTHOR CONTRIBUTIONS}

All authors made substantial contributions to conception and design, acquisition of data, or analysis and interpretation of data; took part in drafting the article or revising it critically for important intellectual content; agreed to submit to the current journal; gave final approval of the version to be published; and agree to be accountable for all aspects of the work. All the authors are eligible to be an author as per the international committee of medical journal editors (ICMJE) requirements/guidelines.

\section{CONFLICTS OF INTEREST}

The authors report no financial or any other conflicts of interest in this work.

\section{ETHICAL APPROVALS}

This study does not involve experiments on animals or human subjects.

\section{PUBLISHER'S NOTE}

This journal remains neutral with regard to jurisdictional claims in published institutional affiliation.

\section{REFERENCES}

Choi CW, Shin JY, Seo C, Hong SS, Ahn EK, Jung YH, Oh JS In vitro anti-inflammatory activity of the components of Amomum tsao-ko in murine macrophage RAW 264.7 cells. Afr J Tradit Complement Altern Med, 2018; 15:26-34.

Diao WR, Zhang LL, Feng SS, Xu JG. Chemical composition, antibacterial activity, and mechanism of action of the essential oil from Amomum kravanh. J Food Prot, 2014; 77:1740-6.

El-Lakany AM, Aboul-Ela MA, Abdel-Kader MS, Badr JM, Sabri NN, Goher Y. Anthraquinones with antibacterial activities from Crucianella maritima L. growing in Egypt. Nat Prod Sci, 2004; 10:63-8.

Hasegawa S, Meguro A, Shimizu M, Nishimura T, Kunoh H. Endophytic actinomycetes and their interactions with host plants. Actinomycetologica, 2006; 20:72-81.

Igarashi Y, Iida T, Yoshida R, Furumai T. Pteridic acids A and B, novel plant growth promoters with auxin-like activity from Streptomyces hygroscopicus TP-A0451. J Antibiot, 2002; 55:764-7.

Kamchonwongpaisan S, Nilanonta C, Tarnchompoo B, Thebtaranonth C, Thebtaranonth Y, Yuthavong Y, Kongsaeree P, Clardy J. An antimalarial peroxide from Amomum krervanh Pierre. Tetrahedron Lett, $1995 ; 36: 1821-4$.

Kwon KB, Kim JH, Lee YR, Lee HY, Jeong YJ, Rho HW, Ryu DG, Park JW, Park BH. Amomum xanthoides extract prevents cytokineinduced cell death of RINm5F cells through the inhibition of nitric oxide formation. Life Sci, 2003; 73:181-91.

Lee JY, Kim SH, Sung SH, Kim YC. Inhibitory constituents of lipopolysaccharide -induced nitric oxide production in BV2 microglia isolated from Amomum tsao-ko. Planta Med, 2008; 74:867-9.

Malti JE, Mountassif D, Amarouch H. Antimicrobial activity of Elettaria cardamomum: toxicity, biochemical and histological studies. Food Chem, 2007; 104:1560-8.
Manulis S, Shafrir H, Epetein E, Lichter A, Barash I. Biosynthesis of indole-3-acetic acid via indole-3-acetamide pathway in Streptomyces spp. Microbiology, 1994; 140:1045-50.

Mathew J, Shiburaj S, George V. Antimicrobial activity of Amomum cannicarpum. Fitoterapia, 2003; 74:476-8.

Mbaveng AT, Kuete V, Nguemeving JR, Penlap BV, Nkengfack AE, Meyer JJM, Lall N, Krohn K. Antimicrobial activity of the extracts and compounds obtained from Vismia guineensis (Guttiferae). Asian J Tradit Med, 2008; 3:211-23.

Meguro A, Ohmura Y, Hasegawa S, Shimizu M, Nishimura T, Kunoh H. An endophytic actinomycete, Streptomyces sp. MBR-52, that accelerates emergence and elongation of plant adventitious roots. Actinomycetologica, 2006; 20:1-9.

Mishra SK, Taft WH, Putnam AR, Ries SK. Plant growth regulatory metabolites from novel actinomycetes. J Plant Growth Regul, $1987 ; 6: 75-84$

Moon SS, Lee JY, Cho SC. Isotsaokoin, an antifungal agent from Amomum tsao-ko. J Nat Prod, 2004; 67:889-91.

National Committee for Clinical Laboratory Standards. Methods for dilution antimicrobial susceptibility tests for bacteria that grow aerobically. Approved standard M7-A5. National Committee for Clinical Laboratory Standards, Wayne, PA, 2000.

Sardi P, Saracchi M, Quaroni S, Petrolini B, Borgonovi GE, Merli S. Isolation of endophytic Streptomyces from surface-sterilized roots. Appl Environ Microbiol, 1992; 58:2691-3.

Taechowisan T, Chaisaeng S, Phutdhawong WS. Antibacterial, antioxidant and anticancer activities of biphenyls from Streptomyces sp BO-07; an endophyte in Boesenbergia rotunda (L.) Mansf A. Food Agric Immunol, 2017; 28:1330-46.

Taechowisan T, Peberdy JF, Lumyong S. Isolation of endophytic actinomycetes from selected plants and their antifungal activity. World J Microbiol Biotechnol, 2003; 19:381-5.

Teresita SM, Hiroe K, Masashi H, Nobuji N. Constituents of Amomum tsao-ko and their radical scavenging and antioxidant activities. J Am Oil Chem Soc, 2000; 77(6):667-73.

Wu HQ, Huang XL, Lin XS, Huang F, Ge FH. Analysis of the essential oils from Amomun kravak Pierre ex Gagnep by GC-MS. Zhong Yao Cai, 2006; 29(8): 788-92.

Wu L, Wu H, Chen L, Yu X, Borriss R, Gao X. Difficidin and bacilysin from Bacillus amyloliquefaciens FZB42 have antibacterial activity against Xanthomonas oryzae rice pathogens. Sci Rep, 2015; 5:12975.

Yin H, Luo JG, Kong LY. Diarylheptanoids from the fruits of Amomum kravanh and their inhibitory activities of nitric oxide production. Phytochem Lett, 2013a; 6:403-6.

Yin H, Luo JG, Kong LY. Tetracyclic diterpenoids with isomerized isospongian skeleton and labdane diterpenoids from the fruits of Amomum kravanh. J Nat Prod, 2013b; 76:237-42.

Zeng Z, Fu L, Ye XN, Zhang T, Meng SJ, Meng CY. Comparison of volatile oil components from fructus amomi rotundus, fructus galangae, semen alpiniae katsumadai and semen myristicae. Chin J Appl Chem, 2012; 29:1316-23.

How to cite this article:

Taechowisan T, Samsawat T, Puckdee W, Phutdhawong WS. Cytotoxicity and antibacterial activities of crude extract of Streptomyces sp. W08, an endophyte of Amomum krervanh Pierre. J Appl Pharm Sci, 2021; 11(08):134-138. 